\title{
A Turning Point to Successful Entrepreneurship in Case Thai Functional Food Company
}

\author{
Sura-at Supachaturat, Rath Pichyangkura, Achara Chandrachai, and Duanghathai Pentrakoon
}

\begin{abstract}
Launching a functional food is a lot of introduced into the market, but there are just some products only to be successful. Therefore, the objective of this article attempt to explain and analyze what is the turning point to success from twenty successful entrepreneurs by face-to-face and group interviews. Result found that the turning points from failure to successful entrepreneurship were technology, marketability and regulation. Thus Functional Food entrepreneurs might be used to three turning points to introduce new functional food into the market and crossing the chasm.
\end{abstract}

Index Terms-Functional food, turning point, success factor, failure factor.

\section{INTRODUCTION}

In the last decades consumer demands in the field of food production have changed considerably. Consumers more believe that foods contribute directly to their health [1].This recent foods are not intended to only satisfy hunger and to provide necessary nutrients for humans but it is greatly motivated by demographic changes, specifically the aging of the population in most developed countries, the higher life expectancy and the desire for an improved quality of life. Moreover, an increase in life-style related diseases, combined with constantly rising health care costs, have stimulated research to identify or produce food with functions that can improve health and well-being, and reduce the risk or delay the onset of major diseases [2]. It is in this context that the concept of functional food has emerged.

The development of functional foods appears to be a long-term trend with important market potential. According to [3] and [4], the market for functional foods is expanding by 7-10 per cent per year. Market size estimates vary widely, from 7-63 billion US Dollar by 2010. This is expected to reach a value of at least 90.5 billion US\$ by 2013 [5]. The important markets of functional food are U.S. followed by Japan and Europe that together has contributed over $90 \%$ of the total sales.

In Thailand, Food innovation has the potential to grow the Thai food industry. As the consumer becomes more interested in health, there is increasing interest in the Functional Food. [6] reported that Thailand's functional food market in 2009 is 19.5 million Baht and market growth are about 7 percent per year as show in Table I.

Recent, launching a new product that claims to be "Functional food" or "food that is good for health" is

Manuscript received May 3, 2014; revised July 5, 2014.

The authors are with the Technopreneurship and Innovation Management Program, Chulalongkorn University, Bangkok, Thailand (e-mail: suraat15@gmail.com) introduced into the market a lot, but there are just some products only to be successful. As results, it is important to identify what factors lead to the success and failure of these ventures. Current academic literature, however, does not offer much insight. Numerous studies focus on success factors for new technology ventures, but the empirical results are often controversial and fragmented [7]. Therefore, the objective of this article attempt to explain and analyze what is the turning point from the failure factors and critical success factors to successful entrepreneurship technology ventures in case Thai functional food companies.

\begin{tabular}{ccc}
\multicolumn{2}{c}{ TABLE I: THAILAND's FUnCTIONAL FOOD MARKET } \\
\hline \hline \multirow{2}{*}{ Years } & $\begin{array}{c}\text { Market volume (mil. } \\
\text { BAHT) }\end{array}$ & $\begin{array}{c}\text { Market growth } \\
(\%)\end{array}$ \\
\hline 2007 & 16.7 & 7.0 \\
2008 & 18.0 & 7.2 \\
2009 & 19.5 & 7.6 \\
\hline \hline
\end{tabular}

\section{THEORETICAL BACKGROUND}

\section{A. Definition of Failure Entrepreneurship}

The term 'failure' is for the most part pejorative, implying that the firm should not have been started in the first place, or that the key actors lacked the required managerial competence or that debts remain unpaid [8]. In market economies, firms fail because they do not produce goods and services desired by customers at prices they are willing to pay; in short, these firms are less competitive than their rivals [9], [10] explored six major factors for entrepreneurial failure and their implications for entrepreneurial success as follows:

1) Undercapitalization refers to any situation where a business cannot acquire the funds they need.

2) Poor Planning such as market research and planning is a key to avoiding although they are expensive and may produce discouraging conclusion. It is a worthwhile investment.

3) Poor Money Management many small businesses fail because their managers get into cash flow binds, are too easy with credit, are too slow on collections or simply spend money on the wrong things.

4) Lack of Expertise and Credibility too many entrepreneurs get involved in ventures that are well beyond their sphere of expertise. While some managerial skills transfer from one situation to another, even corporate giants have found that some things are not as easy to do as they first appear.

5) Lack of Managerial Skill many bright, creative entrepreneurs produce dazzling plans and ideas, but fail in implementing them because they are unable to direct 
the work of other people.

6) Failure to Follow Regulations part of the personality makeup of many entrepreneurs is very important.

\section{B. Definition of Success Entrepreneurship}

The entrepreneur does not exclusively determine the structure of a firm. The environment also plays an important role in determining the structure of the firm. In academic literature a great deal of attention is paid to the influence of the environment on the firm.

Fig. 1 illustrates that the relation between the entrepreneur and success when the impact of the environment on the firm is acknowledged.

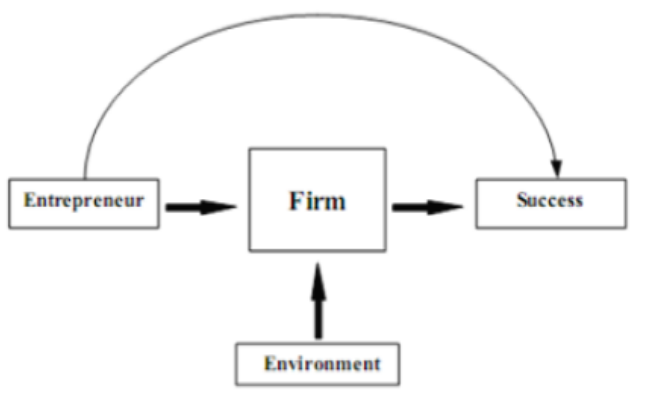

Fig. 1. The relation between the entrepreneur and success when the role of the environment is acknowledged (Source: [11]).

The entrepreneur and the environment determine the structure of the firm. Success of the entrepreneur is measured by success of the firm. The emphasis on profit making as an indicator of success for the entrepreneur motivates the use of profit making as a performance indicator. However, profit making will not be the only indicator of entrepreneurial success taken into consideration. Generated employment and the survival period of the firm is as a measure of performance [11].

Critical Success Factor (CSF) is the term for an element that is necessary for an organization or project to achieve its mission. It is a critical factor or activity required for ensuring the success of a company or an organization. Critical success factors are those few things that must go well to ensure success for a manager or an organization, and, therefore, they represent those managerial or enterprise area, that must be given special and continual attention to bring about high performance. CSFs include issues vital to an organization's current operating activities and to its future success [12] According to [7] a Meta-analysis study, this study suggests the framework of new entrepreneurial firm performance (Fig.2) which is related to five keys significant factors as follows:

- Entrepreneurial team is defined as the management team of the new venture.

- Entrepreneurial opportunities are situations in which new goods, services, raw materials, and organizing methods may be introduced and sold at greater price than their cost of production.

- Entrepreneurial resources include all tangible and intangible assets that a firm may possess and control such as financial means and investments, Intellectual property, partnerships and networks.

- Strategic and organizational fit is defined as the congruence between strategy and organization of the new venture and the driving forces entrepreneurial team, entrepreneurial opportunity, and entrepreneurial resources.

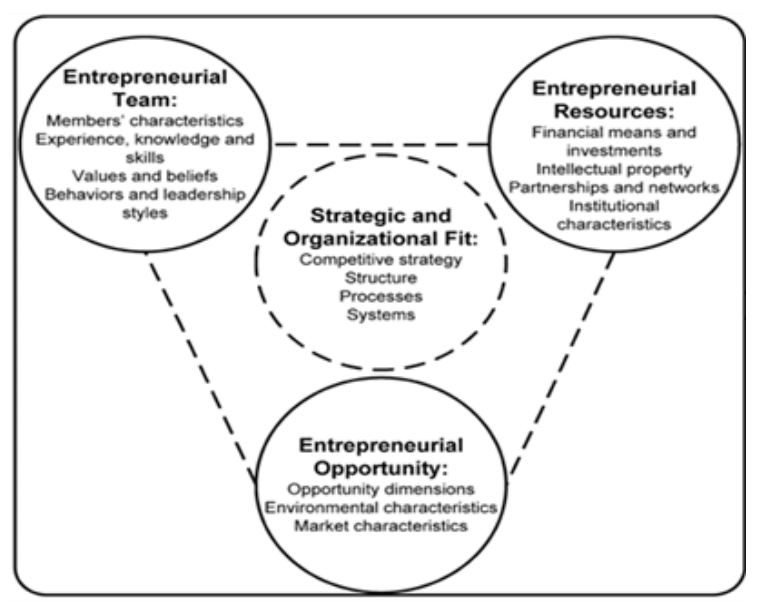

Fig. 2. The framework of new entrepreneur (Source: [7]).

\section{METHODOLOGY/APPROACH}

The purposes of this study are explain and analyze what is the turning point from the failure factors and success factors to successful entrepreneurship technology ventures in case Thai functional food companies. Sequentially, we used two stages to research the turning point for functional foods in Thailand.

First, we used market observation techniques and explored financial statement report which reported at department of business development, ministry of commerce of identified available functional foods products at local retail market and multi-level market.

Second, the successful Thai function food entrepreneurs were selected by sales criteria more than 10 million Baht per month. Used face-to-face and group interviews used during the survey in order to identify the turning point from the failure factors and success factors.

The sample was drawn from Thai function food entrepreneurs. Following prequalification all respondents were interviewed face-to-face with each company and all companies to focus group interviews with an initial semi-structured approach using open-ended questions which focused on reasons motivating their intentions to found a business. Following this, a series of closed ended questions were asked which explored potential failure factors and success factors establishment drawn from the literature.

\section{RESUlts AND DisCUSSION}

\section{A. Functional Product Available in Thailand}

The results of functional product availability at local retail market and multi-level market in Thailand showed in Table II and Table III. According to observation market survey, found that the functional foods found that the functional foods companies mostly attempt to add a benefit such as functional food for brain, functional food for beauty and anti-aging, functional food for well-being and functional food for weight management. They included fruits and vegetables, whole grains, fortified or enhanced foods and beverages, and some dietary supplements. 
TABLE II: FUNCTIONAL FOOD AVAILABLE AT LOCAL RETAIL MARKET AND MULTI-LEVEL MARKET IN THAILAND

\begin{tabular}{|c|c|c|}
\hline Category & Benefit & Brand/Company \\
\hline $\begin{array}{l}\text { functional food } \\
\text { for brain }\end{array}$ & $\begin{array}{l}\text { Omega 3, } \\
\text { Docosacexaenoic acid } \\
\text { (DHA), Soy Peptide, } \\
\text { gamma-aminobutyric } \\
\text { acid (GABA), } \\
\text { Magmesium, } \\
\text { Vitamin B12 }\end{array}$ & $\begin{array}{l}\text { Peptein/ Osotspa } \\
\text { Brane Fit/Ajinomoto } \\
\text { B-ing/Boonrod } \\
\text { Omeg-plus egg/CP } \\
\text { Omega-3 egg/Dr.Hen } \\
\text { Omega juice/Malee } \\
\text { Brand's/Cereboss } \\
\text { Scotch/S \& Sons }\end{array}$ \\
\hline $\begin{array}{l}\text { functional food } \\
\text { for beauty and } \\
\text { anti-aging }\end{array}$ & $\begin{array}{l}\text { Collagen, Antioxident } \\
\text { Q10, } \\
\text { L-glutathione, } \\
\text { VitaminB2 } \\
\text { (Riboflavin), } \\
\text { Vitamin C } \\
\text { (Ascorbic Acid) } \\
\text { Ceremide }\end{array}$ & $\begin{array}{l}\text { Dakara/Tipco } \\
\text { Skinn Fit/Ajinomoto } \\
\text { Puriku/T.C. Pharmaceutical } \\
\text { Brand'sVeta/Cereboss } \\
\text { Scotch Puree/S \& Sons } \\
\text { Abalone Collagen/ Giffarine } \\
\text { Blink Prune/T.C National } \\
\text { Brand Innershine/Cereboss } \\
\text { Collagen C2000/Wuttisak } \\
\text { Acerola Q10/Wuttisak } \\
\text { Gluta-C/Wuttisak } \\
\text { L- Gluta Berry Plus/Verena } \\
\text { Blink CQ/Blink } \\
\text { C-Vitt/ Osotspa } \\
\text { Vitamix/ Dr.Tobi } \\
\text { B-ing/Boonrod } \\
\text { NutriMix/Unif } \\
\text { Extra Coffee Q10 Plus/ } \\
\text { NatureGift }\end{array}$ \\
\hline $\begin{array}{l}\text { functional food } \\
\text { for well-being }\end{array}$ & $\begin{array}{l}\text { Gut health -Probiotic } \\
\text { (bifidobacteria, } \\
\text { Lactobacillus } \\
\text { acidophilus ), } \\
\text { Omega 3, } \\
\text { Vitamin(A,C,D), } \\
\text { Mineral, Bone health } \\
\text { (calcium), Iron, } \\
\text { Lutein, Zine, } \\
\text { Plant Stanol }\end{array}$ & $\begin{array}{l}\text { Yogurt /Yakult } \\
\text { Yogurt /Dutch Mill } \\
\text { Yogurt /Betagen } \\
\text { Yogurt /Foremost } \\
\text { Yogurt /Activia } \\
\text { Hearti Plant Stanol/ Benecol } \\
\text { Brand'sVeta berry/Cereboss } \\
\text { B-ing/Boonrod } \\
\text { M-150/Osotspa } \\
\text { Ranger/ThaiBev } \\
\text { visionLutein/LuteinBev } \\
\text { i healti gac/Osotspa } \\
\text { MANSOME/ T.C. } \\
\text { Pharmaceutical }\end{array}$ \\
\hline
\end{tabular}

TABLE III: FUNCTIONAL FOOD AVAILABLE AT LOCAL RETAIL MARKET AND MULTI-LEVEL MARKET IN THAILAND (CONTINUE)

\begin{tabular}{cll}
\hline \hline Category & \multicolumn{1}{c}{ Benefit } & \multicolumn{1}{c}{ Brand/Company } \\
\hline \hline & & ProSlim/Nescafé \\
functional food & Conjugated linoleic & L-Carnitine apple plus/Verena \\
for weight & acids (CLA), & SP-fiber/Verena \\
management & Antioxident, & B-ing/Boonrod \\
& L-carnitine, Fiber & Nature Gift Coffee/ \\
& & NatureGift \\
\hline \hline
\end{tabular}

According to our face-to-face and group interviews, the twenty successful Thai function food entrepreneurs were selected by sales criteria more than 10 million Baht per month. We divided the interviews into two main factors which are failure and success factors with an initial semi-structured approach using open-ended questions and closed ended questions. The result of the survey as follows;

\section{B. Reasons of Motivating Function Food Business}

Functional food had the potential to grow the Thai food industry. Changes in consumer's lifestyles, awareness and interest in their own health and well-being became important factors. Terms of motivation identified that most Thai functional food were highly promoted to control a beauty balance and anti-aging. The beauty food market has moved main stream in the last three to five years, with companies marketing their products on skin health such as enhanced moisture and elasticity levels, often linked to ingredients like collagen, ceremide and antioxidant CoQ10. It was possible that consumers choose food and drinks are able to be of benefit to mood, beauty body, the digestive system, regulates cholesterol and blood pressure and weight balance.

\section{Success Factors}

From face-to-face and group interviews with twenty successful Thai function food entrepreneurs found that critical success factors as follow to below.

\section{1) Success factor consumer characteristics}

The study found that gender, age and education level of consumers were critical to the purchase decision, and recognition in the functional food products. Especially, gender and age contributed to the decision to buy a function food product. It was found that the decision to buy functional food are female than males in all age ranges because females have interest towards food and health care than males, thus deciding which foods to strengthen protection and reduce the risk of disease. In addition, age was also a factor in the purchase decision. Teen ages could choose function food that control appetite and weight control. While, adults decide bought functional food to brain health, regulate cholesterol and blood pressure.

\section{2) Success factor ability to address unmet need}

The study found that ability to address unmet need, beauty well-being and weight management were introduced into the market very successful. They were growth areas that were not limited to those suffering and about supporting modern life-styles for better looks and youth. Looking at the Japanese market for signs of future trends to come, beauty well-being and weight management (whether in the form of food, beverage or supplement) were well placed to be embraced by consumers looking for experience-orientated lifestyle products.

\section{3) Success factor lifestyle fit}

It was include a fairly broad group of characteristics including convenience, eating habits, purchasing patterns, pill consumption, preferred product forms, vegetarianism and sustainability. Moreover it was meaning to channel for the distribution of functional food that are important for the purchase decision. Drug store was an important channel in the purchase decision, as there is a health expert advice and knowledge in functional food. However No longer were customers willing to seek out products in out-of-the-way health food stores; they expect to purchase where they shop, including convenience stores and the Internet. For today's busy consumer, one-stop-shopping had become the norm.

\section{4) Success factor (4) product characteristics}

Characteristics of the products must have good quality and effectiveness of action by invoking the functions. This was the most important way to build trust and acceptance consumption of functional food. Furthermore, Taste is also most important. [13] reported that taste of the functional food as a key to consumer acceptance of products. [14] reported that consumers are more aware of healthy benefit from using functional foods, safety of functional foods, innovation products of functional foods and functional foods as medicine. 


\section{Failure Factors}

Failure factors as follow to below:

\section{1) Failure factor regulation}

The interview found that the main failure factor of the functional food marketing was the Thai FDA regulation because it could not be falsely claims to treat and reduce the risk of disease on product's label and advertising. Thus it could not be shown about the benefits and value of the product directly. In the UK, functional foods are applicable to general food law. There is no basis for treating functional foods any differently from conventional foods. Products currently on the market rely on consumer awareness of the functional ingredients involved, as medical claims are not allowed to be made for such foods [15]. The regulatory systems worldwide are charged with the responsibility of ensuring consumer health is protected and that they are not being misled and also with creating an environment for industry to grow and develop. The European system for this category of foods is still in its infancy (the Regulation was only published in 2006) whereas in Japan and the USA and health claims have been regulated for almost 20 years. Within all three countries, the systems have both similarities and differences. The regulatory systems in the USA and Japan have accepted that there may be potential in permitting the use of claims where the supporting scientific evidence is not significant [16].

\section{2) Failure factor market timing and sharing}

The research found that market timing and sharing were minor of failure factors. They were the strategy of making buy or sell decisions of financial assets by attempting to predict future market price movements. However, recently functional food in Thailand is going to early maturing phase which a product has become distributed within a market to the fullest possible extent, leaving demand for the product at a minimum.

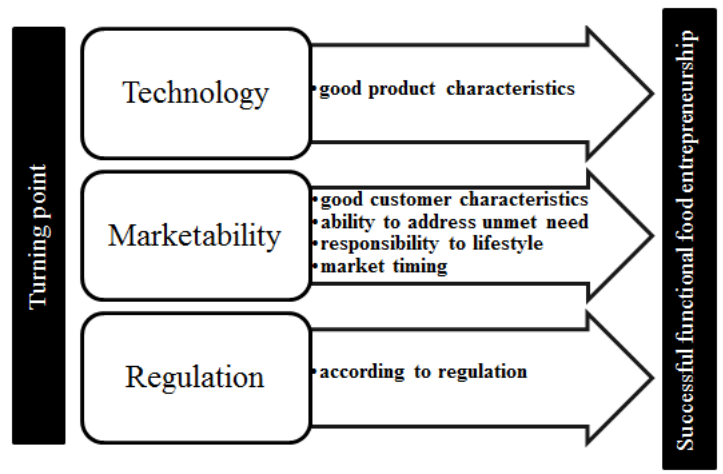

Fig. 2. A turning point from failure to successful entrepreneurship.

After evaluated our face-to-face and group interviews from twenty successful entrepreneurs, we found that the turning points from failure to successful entrepreneurship was to having a good product and customer characteristics, ability to address unmet need, responsibility to lifestyle, market timing strategies and according to regulation as shown in Fig. 2.

\section{CONCLUSIONS}

There are numbers of positive and negative factors that strongly impact on the rise or the fall of entrepreneurship. The turning points of successful entrepreneurship technology ventures in case Thai functional food companies are technology, marketability and regulation. Moreover terms of motivation are highly promoted to control a beauty balance and anti-aging.

\section{RESEARCH LIMITATIONS}

This research is specific to functional food Thai consumption. Thus, the results in this study may not be applicable to cultures in general. Other limitation is related to ten successful Thai function food entrepreneurs interviewees. Implications for managers and entrepreneurs are also presented.

\section{REFERENCES}

[1] B. Mollet and I. Rowland, "Functional foods: At the frontier between food and pharma," Current Opinion in Biotechnology, vol. 13, pp. 483-485, 2002.

[2] S. Arai, "Recent trend in functional food science and the industry in Japan," Biosci Biotechnol Biochem, vol. 6, no. 5, pp. 2017-2029, 2002

[3] S. K. Basu, "Prospects for growth in global nutraceutical and functional food markets: A Canadian perspective," Australian Journal of Basic and Applied Sciences, vol. 1, no. 4, pp. 637-349, 2007.

[4] M. Doyon and J. Labrecque, "Functional foods a conceptual definition," British Food Journal, vol. 110, no. 11, pp. 113-1149, 2008

[5] S. Kuar and M. Das, "Functional foods: an overview," Food Sci. Biotechnol, vol. 20, no. 4, pp. 861-875, 2011.

[6] Kasikorn Research Center, "Direction of the health supplement market," Bangkok, 2007.

[7] M. Song, H. V. D. Bij, and J. Halman, "Success factors in new ventures: A meta-analysis," J. Prod Innov Manag, vol. 25, pp. 7-27, 2008.

[8] G. Beaver, "Small business: Success and Failure," Strat Change, vol. 12, pp.115-122, 2003.

[9] P. R. Coelho and J. E. McClure, "Learning from failure," Mid-American Journal of Business, vol. 20 no. 1, pp. 13-20, 1996.

[10] W. I. Sauser, "Intrapreneurial success: Lessons from entrepreneurial failures," Sam Advanced Management Journal, pp. 32-35, summer 1987.

[11] N. Bosma, M. Praag and G. de Wit, "Determinants of successful entrepreneurship," SCALES, 2000.

[12] A. C. Boynlon and R. W. Zmud, "An assessment of critical success factors,” Sloan Management Review, vol. 25, no. 4, pp. 17-27, 1985.

[13] W. Verbeke, "Functional foods: Consumer willingness to compromise on taste for health?" Food Quality and Preference, vol. 17, no. 1-2, pp. 126-131, 2006.

[14] P. Methakornkulnan, Y. Hsieh, and L. Huang, "Consumer market for functional foods in Thailand," in Proc. the Asian Conference on Psychology \& the Behavioral Sciences 2013, Osaka, Japan, 2013, pp. 148-158.

[15] M. Sadler, "Functional foods: Foods of the future?" Nutrition \& Food Science, vol. 93, no. 4, pp. 11-13, 1993.

[16] F. Lalor and P. G. Wal, "Health claims regulations: Comparison between USA, Japan and European Union," British Food Journal, vol. 113, no. 2, pp. 298-313, 2011.

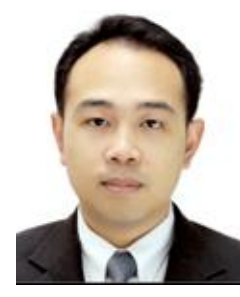

Sura-at Supachatturat was born in 1976 at Bangkok, Thailand. The degrees of education are: B.Sc. in Biotechnology, Kasetsart University; M.Sc in Biotechnology, Kasetsart University; Ph.D. candidate in Technopreneurship and Innovation Management, Chulalongkorn University. He is a $\mathrm{Ph}$.D. student of Technopreneurship and Innovation Management program, Chulalongkorn University, Bangkok, Thailand. Furthermore, he is working as a department manager with the National Innovation Agency (public organization) of Thailand. He have been spending years as a lecturer at MBA Innovation Management Program, Ramkhamhaeng University and has more than 10 years of functional food experience in Thai food industry. He was interested in innovation management and innovation system. 